\title{
Mexican Onyx Waste as Active Material and Active Material's Precursor for Conversion Anodes of Lithium Ion Batteries
}

\author{
Enrique Quiroga-González ${ }^{1 *}$ and Emma Morales-Merino ${ }^{2}$ \\ ${ }^{1}$ Institute of Physics, Benemérita Universidad Autónoma de Puebla, Puebla, Mexico, ${ }^{2}$ Faculty of Electronic Sciences, Benemérita \\ Universidad Autónoma de Puebla, Puebla, Mexico
}

For the first time a limestone has been used as active material or active material's precursor for electrodes of Li ion batteries. Limestones are very abundant, what is a condition for a sustainable development of energy storage devices. Mexican onyx has been used as a

OPEN ACCESS

Edited by:

Ali Eftekhari,

Queen's University Belfast,

United Kingdom

Reviewed by:

Jianguo Huang,

Zhejiang University, China

Xifei Li,

Xi'an University of Technology, China Liqiang Mai,

Wuhan University of Technology,

China

*Correspondence:

Enrique Quiroga-González equiroga@ieee.org

Specialty section:

This article was submitted to Electrochemical Energy Conversion and Storage,

a section of the journal Frontiers in Energy Research

Received: 11 August 2020 Accepted: 22 January 2021

Published: 23 February 2021

Citation:

Quiroga-González E and Morales-Merino E (2021) Mexican

Onyx Waste as Active Material and Active Material's Precursor for Conversion Anodes of Lithium Ion Batteries.

Front. Energy Res. 9:593574. doi: 10.3389/fenrg.2021.593574 model of limestone in this work, mainly composed of calcite (calcium carbonate). Waste powder of this material from handcraft production was used, reducing costs. The material was carbonized and pyrolyzed, producing calcium oxide covered with carbon. Mexican onyx either treated or untreated works well as anode material for Li ion batteries, storing charges by conversion. Despite the grains of this material were as big as $50 \mu \mathrm{m}$, the material with no treatment showed a maximum Li storage capacity of $530.16 \mathrm{mAh} / \mathrm{g}$ at C/ 3.3, while the pyrolyzed one showed a maximum reversible capacity of $220 \mathrm{mAh} / \mathrm{g}$ at $1.37 \mathrm{C}$ and of $158 \mathrm{mAh} / \mathrm{g}$ at $5.48 \mathrm{C}$, performance even better than the performance of graphite.

Keywords: mexican onyx, calcium carbonate, calcium oxide, conversion anode material, lithium ion battery, high rate storage, waste revalorization, sustainable energy storage

\section{INTRODUCTION}

The future of energy storage systems is not simply relying on good performance, but on sustainability. Of special interest is the development of batteries with abundant materials. In the case of anodes of Li ion batteries, $\mathrm{Si}$ is one of the materials catching much attention in the latest years, since is the most abundant material in Earth's crust and presents the highest lithium storage capacity among anode materials. Practical use of Si has been already accomplished, assuring areal capacities higher than $5 \mathrm{mAh} / \mathrm{cm}^{2}$ (Quiroga-González et al., 2013). However, due to the costs of the production process of such anodes, it is not possible to compete with graphite, the most commonly used material for anodes, even when its capacity is more than 10 times lower (Jin et al., 2017). To reduce costs, cheaper and simpler processes have been tested (Pérez-Díaz et al., 2019), but one is coming to the limits of the cost of the raw material, which is still elevated due to the purification of $\mathrm{Si}$ (it is in the form of silicates in nature). It is desirable to use the material in the unprocessed form, e.g., in the form of sand, but until now there are no reports on that; the closest report is about the magnesiothermic treatment of sand to obtain Si to use it as active material in Li ion batteries (Favors et al., 2015).

There is a report about a different mineral, used in its natural form in $\mathrm{Li}$ ion batteries: calcite $\left(\mathrm{CaCO}_{3}\right)$ (Minakshi et al., 2018). Eggshells (primary composed of calcite) were simply milled to form a powder that acted as active material of a Li ion battery, which was handled as a supercapacitor by the authors. The voltage range at which the electrodes were operated (below $1.2 \mathrm{~V}$ ) is in the range of 
anodes of $\mathrm{Li}$ ion batteries. Later, the same research group reported another work using the material as a precursor to obtain $\mathrm{CaO}$, to use it in electrodes of supercapacitors with aqueous electrolyte (Minakshi, et al., 2019). The results presented in both reports were promising, indicating that $\mathrm{CaCO}_{3}$ is a good candidate to be used as active material of energy storage devices, particularly as anode in $\mathrm{Li}$ ion batteries. Another abundant natural source of $\mathrm{CaCO}_{3}$ are limestones, from which there is a vast variety (Wright, 1992). A kind of limestone is the Mexican onyx (from now on called Mx-Onyx), which has been reported to be composed mainly of $\mathrm{CaCO}_{3}$, with some other minerals in very small amount causing the color (Márquez-Mata, et al., 2019). "Onyx" is used as a descriptive term used to denote parallel banded gemstones, even when the banding is contorted, as is the case of Mx-Onyx (Manutchehr-Danai, 2013). It is important to mention that Mx-Onyx is widely used to produce handcrafts, and a lot of powder of that material is produced when sawing it. That powder has normally no further use, and one can obtain it at no cost. The present work deals with the use of the waste powder of $\mathrm{Mx}$-Onyx to produce anodes for $\mathrm{Li}$ ion batteries. This is the first time any limestone is used for that purpose. The material is used as it is, and pyrolyzed.

\section{MATERIALS AND METHODS}

Mx-Onyx handcraft waste powder was obtained from the region of Santiago Acatlán, in Puebla, Mexico. It had a white color. This material was used as it is or pyrolized to produce anodes for $\mathrm{Li}$ ion batteries. The pyrolysis was performed in order to obtain $\mathrm{CaO}$. As this material presents a very limited electronic conductivity (below $10^{-6} \Omega^{-1} \mathrm{~cm}^{-1}$ even at $600 \mathrm{~K}$ ) (Mee, 1961), Mx-Onyx was covered with carbon hydrothermally prior to pyrolysis, by the following procedure: $1.5 \mathrm{~g}$ sucrose were dissolved in $7 \mathrm{ml}$ deionized water; then $3 \mathrm{~g}$ Mx-Onyx powder were added to the mixture, and this was stirred magnetically for $10 \mathrm{~min}$. Afterward, under continuous magnetic stirring, $\mathrm{H}_{2} \mathrm{SO}_{4}(0.7 \mathrm{ml})$ was added dropwise. The mixture was sealed in a $20 \mathrm{ml}$ teflon-lined stainless steel autoclave, and left in an oven at $180^{\circ} \mathrm{C}$ for $24 \mathrm{~h}$. The autoclave was then left to cool down at room temperature. The product was washed with deionized water with the aid of an ultrasonic bath.

Pyrolysis was performed in a tubular furnace under $\mathrm{N}_{2}$ flow. Heating was applied following the program: 1 . Ramp of $5^{\circ} \mathrm{C} / \mathrm{min}$ until $700^{\circ} \mathrm{C} ; 2$. Ramp of $10^{\circ} \mathrm{C} / \mathrm{min}$ from 700 to $950^{\circ} \mathrm{C} ; 3$. Constant temperature of $950^{\circ} \mathrm{C}$ for $3 \mathrm{~h}$. Then the oven was turned off and let to cool down under constant $\mathrm{N}_{2}$ flow. The powder product $(\mathrm{Mx}-$ Onyx-950C) had a dark brown color. The temperature was selected to assure certain graphitic character of carbon, and to obtain $\mathrm{CaO}$, since the temperature to decompose all the carbonates either from eggshells or limestone is $900^{\circ} \mathrm{C}$ (Ferraz et al., 2018). The carbon content of the product was $30.7 \mathrm{wt} \%$, determined by weighting before and after every processing step.

The morphology of Mx-Onyx was analyzed with a with a FESEM (field emission scanning electron microscope) JEOL JSM$7500 \mathrm{~F}$, which is equipped with an EDX (Energy Dispersive X ray spectrometer) detector to perform elemental analysis. Its powder
XRD (X ray diffraction) pattern was collected with a PanalyticalEmpirian in reflection mode using $\mathrm{Cu}-\mathrm{Ka}$ radiation, with a resolution of $0.04^{\circ}$. Raman microscopy was performed on all the samples using a Horiba LabRam HR, with a $\times 50$ objective and a grating of 600 lines $/ \mathrm{mm}$, in the range of $100-2,000 \mathrm{~cm}^{-1}$. Subpixel scans were performed in order to obtain a higher resolution $\left(0.56 \mathrm{~cm}^{-1}\right)$.

Battery anodes were prepared out of a paste made of the active material (either Mx-Onyx or Mx-Onyx-950C), carbon black and carboxymethyl cellulose (CMC) in a 30: 70: 10 weight proportion. The large amount of carbon black was used to assure a good electrical contact of the active material, which is in the form of particles of up to $50 \mu \mathrm{m}$. Deionized water was added dropwise to the mixture of the materials while mixing to form a slurry. This paste was casted on a $\mathrm{Cu}$ foil, which acts as a current collector. The samples were dried in a hot air oven at $80^{\circ} \mathrm{C}$ for $24 \mathrm{~h}$, and then introduced in an Ar filled globe box. The anodes were assembled in half battery cells with metallic Li as counter electrode and a Whatman filter paper as a separator. The electrolyte was a solution $1 \mathrm{M}$ of LiPF6 in ethylene carbonate and dimethyl carbonate in a proportion 50:50 v/v. Cyclic voltammetry was performed in a BioLogic potentiostat at a voltage sweep rate of $0.2 \mathrm{mV} / \mathrm{s}$. Charge/discharge cycling tests were performed with an MTI battery cycler in galvanostatic mode.

\section{RESULTS AND DISCUSSION}

\section{Composition and Structure of the Materials}

A SEM micrograph of Mx-Onyx waste powder is shown in Figure 1A. As can be observed, the powder is composed of particles of irregular form. The particles have sizes ranging from 1 to $150 \mu \mathrm{m}$ approximately. For the preparation of the battery anodes, the largest particulates (larger than $50 \mu \mathrm{m}$ ) were separated by hand, and just the finest powder was used. EDX spectra were collected on different areas of the powder (as indicated on the micrograph). A typical spectrum is shown in Figure 1B. One can identify the lines of $\mathrm{C}, \mathrm{O}, \mathrm{S}, \mathrm{Mg}$, and $\mathrm{Ca}$. The estimated composition of the material is $\mathrm{CaMg}_{0.008(0.0026)}$ $\mathrm{O}_{1.61(0.061)} \mathrm{S}_{0.031(0.0002)} \mathrm{C}_{\mathrm{x}}$; the values in parenthesis are the standard deviations. The amount of carbon was not determined, since EDX could overestimate carbon content due to carbon tape used to fix the sample to the holder. As can be inferred, $\mathrm{Mg}$ and $\mathrm{S}$ are present in the mineral as impurities (they are present in concentrations of less than 3 atomic \%), maybe in the form of other minerals. The XRD pattern of Mx-Onyx (Figure 2) shows the reflexes of $\mathrm{CaCO}_{3}$ in the form of the calcite mineral (Wang et al., 2018). No secondary phases could be identified, indicating that Mx-Onyx is mainly composed of calcite.

To confirm the composition of Mx-Onyx, Raman microscopy was used to analyze the material. Its Raman spectrum together with similar Raman spectra of known minerals are shown in Figure 3. The spectrum of Mx-Onyx can be explained as a linear combination of the spectra of calcite $\left(\mathrm{CaCO}_{3}, \mathrm{RRUF}\right.$ ID R040070), whewellite $\left(\mathrm{CaC}_{2} \mathrm{O}_{4}{ }^{\star} \mathrm{H}_{2} \mathrm{O}\right.$, RRUF ID R050526) and gypsum $\left(\mathrm{CaSO}_{4}{ }^{\star} 2 \mathrm{H}_{2} \mathrm{O}\right.$, RRUF ID R040029) 


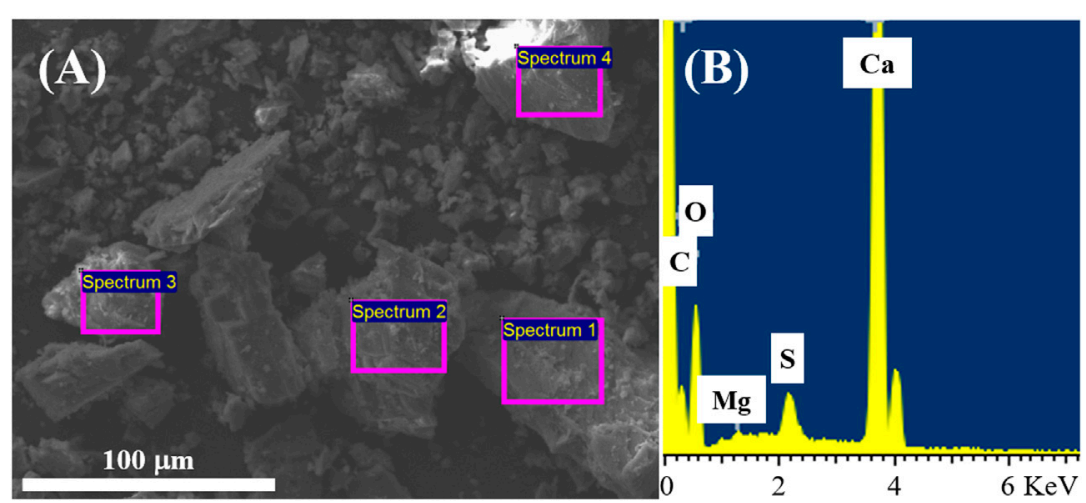

FIGURE 1 | (A) Typical SEM micrograph of Mx-Onyx, indicating sections where EDX analysis was performed. (B) Typical EDX spectrum of Mx-Onyx.

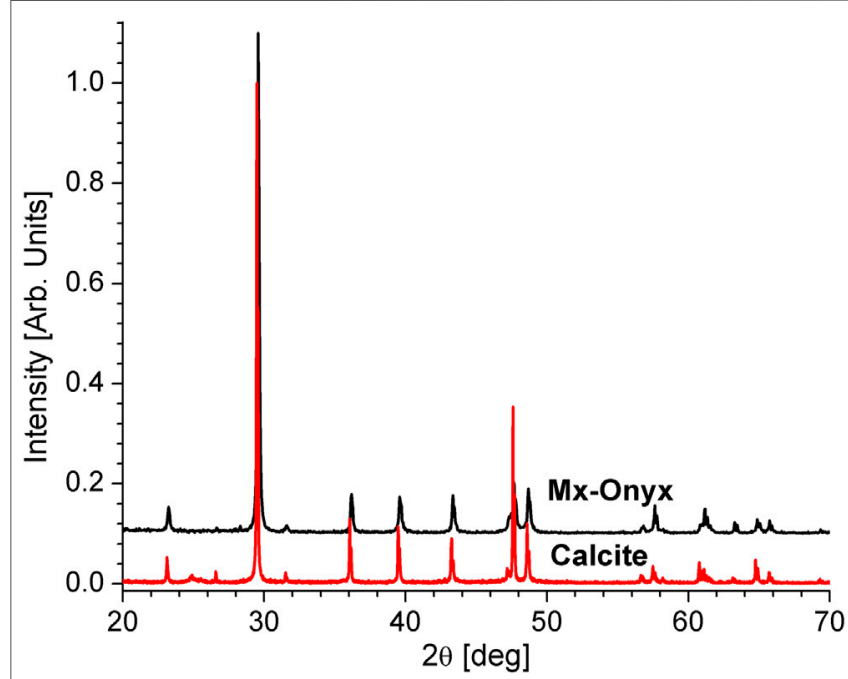

FIGURE 2 |XRD pattern of Mx-Onyx. The pattern of calcite (Wang et al., 2018 ) is presented as reference.

(Lafuente et al., 2015). The ratio of the intensities of the most significative peaks of calcite: whewellite: gypsum is 100: 2.2: 1.7. Then one can infer that whewellite and gypsum are present as impurities, as expected from the EDX elemental analysis. The peak marked with * corresponds to diamond (May et al., 2008), which could be originated from the saw used for cutting the MxOnyx. The peak marked with ${ }^{* *}$ is related to the previous one, since may come from $\mathrm{CO}_{2}$ inclusions in diamond (Palyanov et al., 2016). The peaks enclosed in a rectangle are originated from hydration of the mineral, forming calcium hydroxide, which causes very intense bands even in small quantities (Liu and Sun, 2016).

The Raman spectrum of the Mx-Onyx pyrolized at $950^{\circ} \mathrm{C}$ (Mx-Onyx-950C) is shown in Figure 4. It is expected that calcite and whewellite completely convert to $\mathrm{CaO}$ at temperatures above, even in the presence of residual $\mathrm{CO}_{2}$ gas $900^{\circ} \mathrm{C}$ (Ferraz et al., 2018; Hourlier, 2019). Thus the typical bands of this compound are expected. As can be observed, the spectrum of Mx-Onyx-950C is

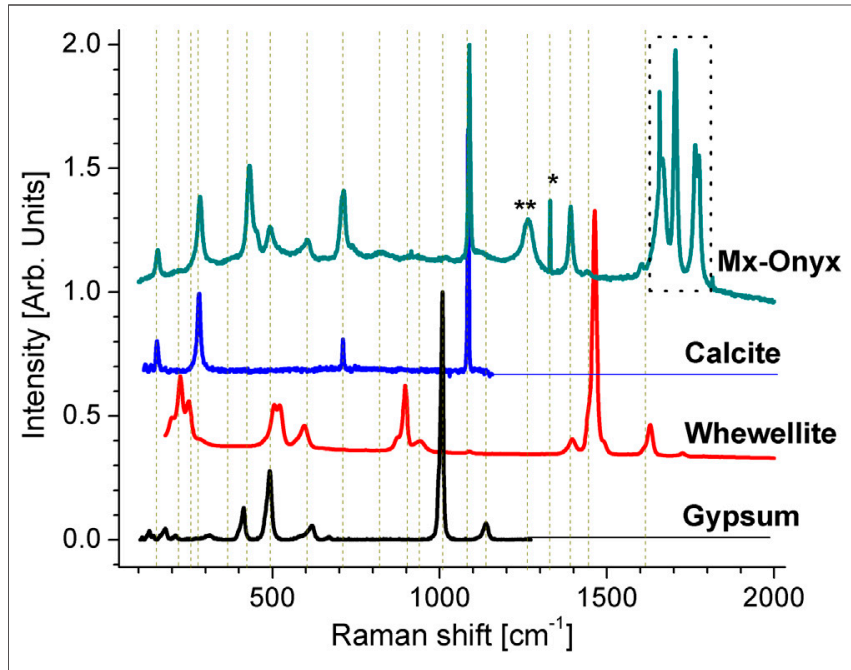

FIGURE 3 | Raman spectrum of Mx-Onyx together with the spectra of calcite, whewellite and gypsum (Lafuente et al., 2015). The vertical dashed lines are an aid to the eye. The enclosed section is an infication of hydration. The peak marked with * corresponds to diamond, while the one marked with ${ }^{* *}$ corresponds to diamond with inclusions of $\mathrm{CO}_{2}$.

very similar to the one of $\mathrm{Mx}$-Onyx, but with the peaks reduced in intensity and broadened. It is reported that the spectrum of $\mathrm{CaO}$ is very similar to the one of $\mathrm{CaCO}_{3}$ (Ferraz et al., 2018), what has been attributed to the high reactivity of $\mathrm{CaO}$ tat reacts with $\mathrm{CO}_{2}$ of the ambient (at least at the surface) producing $\mathrm{CaCO}_{3}$ (Schmid and Dariz, 2014). Actually, $\mathrm{CaO}$ has been investigated to capture $\mathrm{CO}_{2}$ and transform it to $\mathrm{CaCO}_{3}$ (Morales-Flórez et al., 2015). The bands of hydration (above $1,500 \mathrm{~cm}^{-1}$ ) continue appearing, since the sample is exposed to ambient moisture. Gypsum converts at $950^{\circ} \mathrm{C}$ into $\mathrm{CaS}$ and $\mathrm{CO}_{2}$ in the presence of carbon (Jia et al., 2016). This gives rise to broad Raman bands below $400 \mathrm{~cm}^{-1}$ (Avril et al., 2013), which can be appreciated in the spectrum of Mx-Onyx-950C (Figure 4). The broad bands named D and G are typical of carbonaceous materials. D denotes a tetrahedral bonding of $\mathrm{C}$ (sp3 hybridization), which is considered "defectual" in relation to the bonding in plane (sp2 


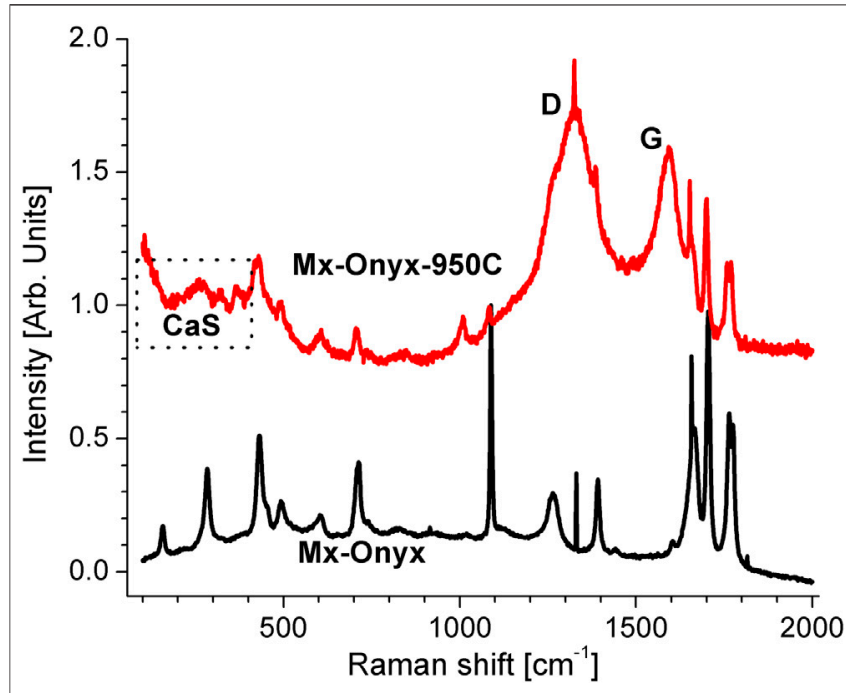

FIGURE 4 | Raman spectra of Mx-Onyx and Mx-Onyx-950C.

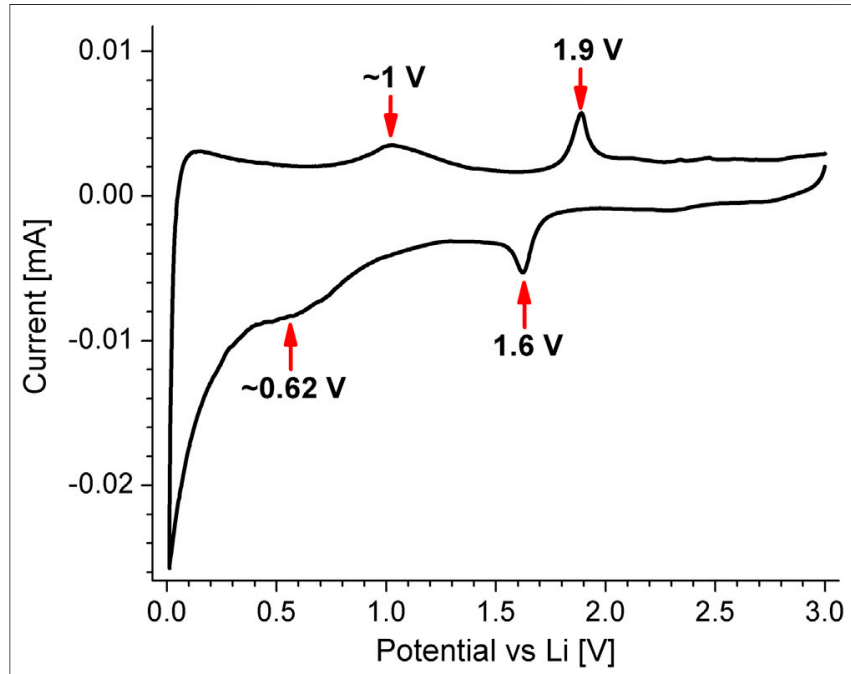

FIGURE 5 | Cyclic voltammogram of a half battery cell with Mx-Onyx as working electrode.

hybridization), which produces the G band typical of graphite (Santamaría-Juárez et al., 2019). These bands can be ascribed to the carbon coating of the particles of M-Onyx-950C, deposited prior to pyrolysis.

\section{Electrochemical Performance of the Materials in Li Ion Batteries}

Battery half cells using Mx-Onyx as working electrode and $\mathrm{Li}$ metal as counting electrodes, were submitted to cyclic voltammetry of $0.01-3 \mathrm{~V}$, to identify the redox processes occurring in the material, in accordance to carbonate based compounds used in batteries, like $\mathrm{CoCO}_{3}$ (Tian et al., 2015).

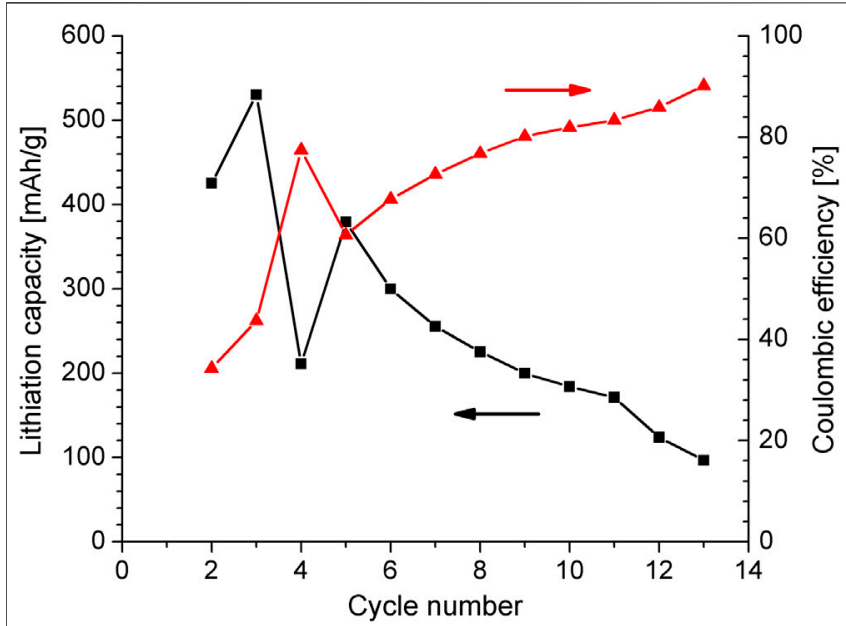

FIGURE 6 | Plot of capacity and Coulombic efficiency vs. cycle number of a half battery cell with Mx-Onyx as working electrode.

The cyclic voltammogram of Mx-Onyx is shown in Figure 5; its shape and potentials of the peaks are close to those of the reference. The redox couple of 1.6 and $1.9 \mathrm{~V}$ is most probably related to the reversible reaction Eq. 1:

$$
\mathrm{CaCO}_{3}+2 \mathrm{Li} \leftrightarrow \mathrm{Ca}+\mathrm{Li}_{2} \mathrm{CO}_{3},
$$

while the redox couple at 0.62 and $1 \mathrm{~V}$ relates to Eq. 2:

$$
\mathrm{Li}_{2} \mathrm{CO}_{3} \leftrightarrow \mathrm{Li}_{2} \mathrm{O}+\mathrm{LiC} .
$$

This reaction mechanism has been evidenced by different techniques (Tian et al., 2015). In a recent report (Minakshi et al., 2018), where eggshell powder (calcite) was used in a $\mathrm{Li}$ ion battery, the authors indicated that no redox processes occur. However, the low conductivity of the material, together with the high voltage sweep rate used for the cyclic voltammetry measurements of that work, could have not been ideal for the identification of the redox peaks. Even though, current kinks could be observed.

If one considers the whole potential range where all redox peaks appear, the material would not be useful neither as cathode nor as anode of Li ion batteries. However, one can shorten the potential window to enable just the process of Eq. 2. In this way the material can be considered an anode, which works through a conversion mechanism. A half battery cell of Mx-Onyx was charge/discharge cycled in the voltage range of $0.01-1.2 \mathrm{~V}$ vs. Li. The cycling results are presented in Figure 6. The results are presented from the second cycle, for better visualization. In the first cycle a large capacity loss of $400 \mathrm{mAh} / \mathrm{g}$ occurs, due to the formation of a Solid Electrolyte Interface (SEI). The maximum capacity of the anode, after SEI formation, is of $530.16 \mathrm{mAh} / \mathrm{g}$. This value is high in comparison with the capacity of graphite, the most used anode material, of about $370 \mathrm{mAh} / \mathrm{g}$. However, a rapid capacity fade of $43.33 \mathrm{mAh} / \mathrm{g}$ per cycle occurs, and after 13 cycles the battery stops working. This should be due to the big particles of active material, which may be fragmented during the 

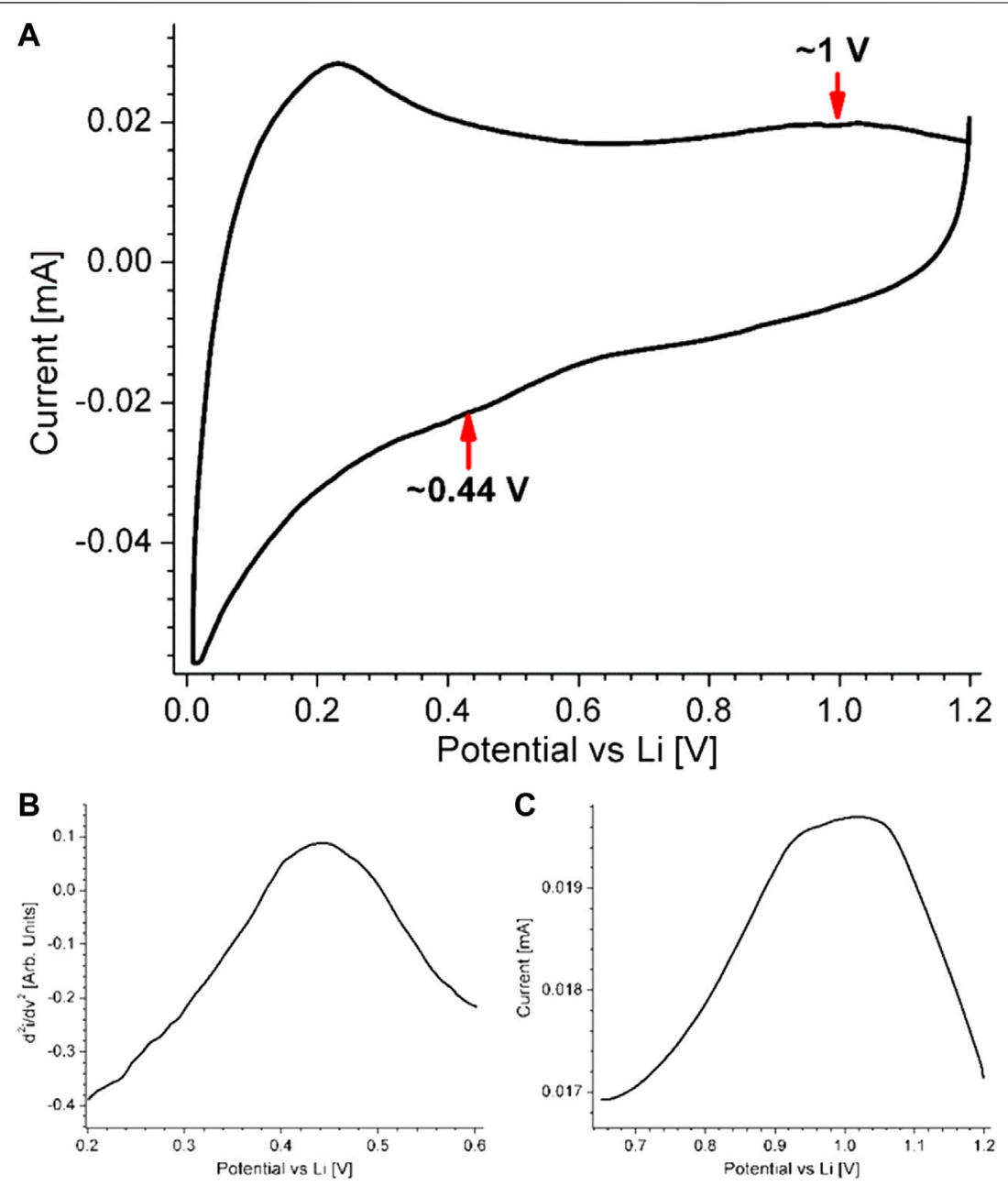

FIGURE 7 | A) Cyclic voltammogram of a half battery cell with Mx-Onyx-950C as working electrode. (B) Second derivative of the lithiation section of the curve, to denote the inflection point at $0.44 \mathrm{~V}$. (C) Zoom in at the delithiation region of the curve to denote the peak at around $1 \mathrm{~V}$.

conversion process of each cycle, causing a loss of contact (big portions of material start to behave as inactive material). At cycle 14 , the anode loses the contact completely. On the other hand, the Coulombic efficiency is about $32 \%$ in the second cycle and is steadily improved until a value of $90 \%$ in cycle 13 , indicating that there is a formation process, tending to a stationary stage; however, the stability is being reached at the time of loss of contact. For future work, a finer powder of active material should be considered. The current density for the experiment was $159 \mathrm{~mA} / \mathrm{g}$, in the same range of the report by (Minakshi et al., 2018), corresponding to a rate of $\mathrm{C} / 3.3$. In that work the authors report a capacitance of $137 \mathrm{~F} / \mathrm{g}$, corresponding to a capacity of $45.6 \mathrm{mAh} / \mathrm{g}$, considering an operation voltage of $1.2 \mathrm{~V}$. This low capacity could indicate that the conversion processes occurred just very shallow in the active material, probably because the voltage limits were reached very fast given by the large ohmic drops. That is why the cycling performance looks like the one of a supercapacitor.

A cyclic voltammogram of a half battery cell with Mx-Onyx950C is shown in Figure 7A. A redox couple can be observed, with peak positions at $0.44 \mathrm{~V}$ (lithiation) and $1 \mathrm{~V}$ (delithiation), consistent with the values of metal oxides. To make the peaks more evident, the second derivative of the lithiation section of the curve was calculated (Figure 7B), since it is present in the form of a shoulder (inflection point); on the other hand, a zoom was made to the delithiation section of the curve (Figure 7C). It is important to remember that Mx-Onyx-950C is mainly composed of $\mathrm{CaO}$. The position of the lithiation peak depends on the metal; e.g., it is at $0.3 \mathrm{~V}$ for $\mathrm{ZnO}$ (Park et al., 2016), while it is of $0.75 \mathrm{~V}$ for $\mathrm{SnO}$ (Hu et al., 2015). The delithiation peak is at $1 \mathrm{~V}$ for $\mathrm{ZnO}$ (Park et al., 2016), while it is of $1.1 \mathrm{~V}$ for $\mathrm{SnO}$ (Hu et al., 2015). Taking into account the reaction mechanisms presented in the reports of the different metal oxides, the reaction mechanism of lithiation and delithiation of Mx-Onyx-950C should be as follows Eq. 3:

$$
\mathrm{CaO}+2 \mathrm{Li} \leftrightarrow \mathrm{Ca}+\mathrm{Li}_{2} \mathrm{O}
$$

From this equation, the expected capacity for pure $\mathrm{CaO}$ is of $950 \mathrm{mAh} / \mathrm{g}$, and of $657.7 \mathrm{mAh} / \mathrm{g}$ for the $\mathrm{CaO} / \mathrm{C}$ composite $(\mathrm{Mx}-$ Onyx-950C). The CaS present in Mx-Onyx-950C in very small 


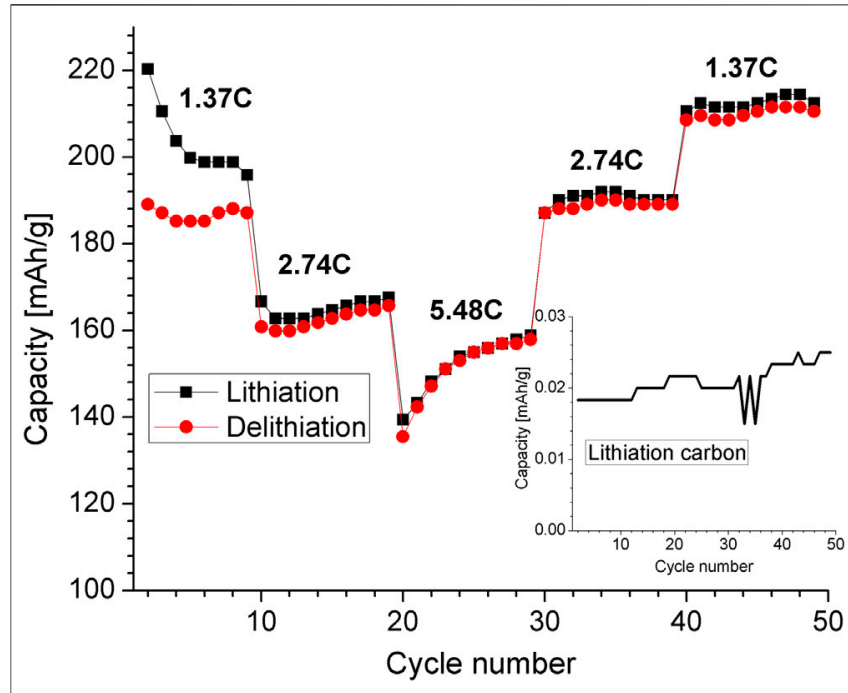

FIGURE 8 | Plot of capacity vs. cycle number of a half battery cell with Mx-Onyx-950C as working electrode, tested at different charge/ discharge rates.

amount (the atomic proportion of oxygen to sulfur in the MxOnyx precursor was around 52), may act as inactive material after the first cycle, since the reaction with sulfides like $\mathrm{SnS}$ occurs above $1.5 \mathrm{~V}$ (Wang et al., 2013). Considering that the voltammetric peaks are broad, the voltage window considered for charge/discharge cycling for the Mx-Onyx-950C $(0.02-1.4 \mathrm{~V})$ was a bit wider than the one selected for $\mathrm{Mx}$ Onyx. Battery cycling results for Mx-Onyx-950C at different rates are shown in Figure 8. The performance of the carbon used for coating (without $\mathrm{CaO}$ ) under the same current densities, is shown as inset, to denote that this material provides less than $0.03 \mathrm{mAh} / \mathrm{g}$. For a better visualization, the results are plotted from the second cycle. The capacity of $\mathrm{Mx}-$ Onyx-950C is of $920 \mathrm{mAh} / \mathrm{g}$ in the first cycle, while it is of $220 \mathrm{mAh} / \mathrm{g}$ in the second cycle. Considering that the theoretical capacity of the material is $657.7 \mathrm{mAh} / \mathrm{g}, 262.3 \mathrm{mAh} / \mathrm{g}$ may go to the formation of a SEI layer. Having a capacity of just $220 \mathrm{mAh} /$ $\mathrm{g}$ in the second cycle indicates that the material can be delithiated just $33.48 \%$. The substitution reaction of Eq. 3 may not be reversible as expressed. After the second cycle, the reaction mechanism should be Eq. 4:

$$
\mathrm{Li}_{4 / 3} \mathrm{O}+2 / 3 \mathrm{Li} \leftrightarrow \mathrm{Li}_{2} \mathrm{O} .
$$

The current densities used for the test of Figure 8 were of 300, 600 and $1,200 \mathrm{~mA} / \mathrm{g}$, corresponding to $\mathrm{C}$ rates of $1.37 \mathrm{C}, 2.74 \mathrm{C}$ and $5.48 \mathrm{C}$ if the maximum capacity is $220 \mathrm{mAh} / \mathrm{g}$. The capacity is competitive even at $5.48 \mathrm{C}(158 \mathrm{mAh} / \mathrm{g})$. In the work by (Minakshi, et al., 2019), where $\mathrm{CaO}$ was obtained from eggshells at $900^{\circ} \mathrm{C}$, the authors tested the material as active material of supercapacitors, reporting a capacitance of $53.57 \mathrm{~F}$ / $\mathrm{g}$, an energy density of $14.5 \mathrm{Wh} / \mathrm{kg}$, and a power density of $525 \mathrm{~W} / \mathrm{kg}$. Since the device worked at $1.6 \mathrm{~V}$, it is possible to estimate that the capacity was $23.61 \mathrm{mAh} / \mathrm{g}$, at $328 \mathrm{~mA} / \mathrm{g}$. This means that the capacity is much lower than the capacity obtained in the present work, and was tested at lower charging rates. Graphite, the most used anode material for $\mathrm{Li}$ ion batteries, presents capacities of around $110 \mathrm{mAh} / \mathrm{g}$ at charging rates of about 5C (Mao et al., 2018; Mo et al., 2019).

\section{CONCLUSION}

Mexican onyx (Mx-Onyx) was evidenced to be composed mainly of calcite $\left(\mathrm{CaCO}_{3}\right)$ with impurities of whewellite $\left(\mathrm{CaC}_{2} \mathrm{O}_{4}{ }^{\star} \mathrm{H}_{2} \mathrm{O}\right)$ and gypsum $\left(\mathrm{CaSO}_{4}{ }^{\star} 2 \mathrm{H}_{2} \mathrm{O}\right)$. The pyrolysis of the material, with a previous hydrothermal carbonization, allowed to obtain $\mathrm{CaO}$ covered with carbon (Mx-Onyx-950C). Impurities of $\mathrm{CaS}$ are present in the pyrolysis product, but have no evident effect in the electrochemical performance of the material. Both materials worked properly as anode material in Li ion battery half cells, with conversion mechanisms. Mx-Onyx showed a high capacity of $530.16 \mathrm{mAh} / \mathrm{g}$, with a bad cyclability. In contrast, Mx-Oyx950C exhibited a moderate capacity of $220 \mathrm{mAh} / \mathrm{g}$ at $1.37 \mathrm{C}$ and $158 \mathrm{mAh} / \mathrm{g}$ at $5.48 \mathrm{C}$. This result is exceptional, since the performance at high rates was even better than the performance of graphite, and was synthesized from Mx-Onyx handcrafting waste by simple and economical methods. For future work it is envisioned to reduce the particle sizes of the active materials to further improve their performance as anode of $\mathrm{Li}$ ion batteries (for this work, particles with sizes of up to $50 \mu \mathrm{m}$ were used).

\section{DATA AVAILABILITY STATEMENT}

The original contributions presented in the study are included in the article/Supplementary Material, further inquiries can be directed to the corresponding author.

\section{AUTHOR CONTRIBUTIONS}

EM-M performed the experiments. EQ-G proposed the project, performed data analysis and wrote the manuscript.

\section{FUNDING}

The project was funded by VIEP-BUAP through the project VIEP-2019-100523072.

\section{ACKNOWLEDGMENTS}

The authors thank the Mexican Energy Storage Network, which supported the presentation of the present project in its flagship conference "Energy Storage Discussions". 


\section{REFERENCES}

Avril, C., Malavergne, V., Caracas, R., Zanda, B., Reynard, B., Charon, E., et al. (2013). Raman spectroscopic properties and Raman identification of CaS-MgS$\mathrm{MnS}-\mathrm{FeS}-\mathrm{Cr}_{2} \mathrm{FeS}_{4}$ sulfides in meteorites and reduced sulfur-rich systems. Meteorit. Planet. Sci. 48, 1415-1426. doi:10.1111/maps.12145

Favors, Z., Wang, W., Bay, H., Mutlu, Z., Ahmed, K., Liu, C., et al. (2015). Scalable synthesis of nano-silicon from beach sand for long cycle life Li-ion batteries. Sci. Rep. 4, 5623. doi:10.1038/srep05623

Ferraz, E., Gamelas, J. A. F., Coroado, J., Monteiro, C., and Rocha, F. (2018). Eggshell waste to produce building lime: calcium oxide reactivity, industrial, environmental and economic implications. Mater. Struct. 51, 115. doi:10.1617/ s11527-018-1243-7

Hourlier, D. (2019). Thermal decomposition of calcium oxalate: beyond appearances. J. Therm. Anal. Calorim. 136, 2221-2229. doi:10.1007/s10973018-7888-1

Hu, R., Chen, D., Waller, G., Ouyang, Y., Chen, Y., Zhao, B., et al. (2015). Dramatically enhanced reversibility of $\mathrm{Li}_{2} \mathrm{O}$ in $\mathrm{SnO}_{2}$-based electrodes: the effect of nanostructure on high initial reversible capacity. Energy Environ. Sci. 9, 595-603. doi:10.1039/C5EE03367E

Jia, X., Wang, Q., Cen, K., and Chen, L. (2016). An experimental study of $\mathrm{CaSO}_{4}$ decomposition during coal pyrolysis. Fuel 163, 157-165. doi:10.1016/j.fuel. 2015.09.054

Jin, Y., Zhu, B., Lu, Z., Liu, N., and Zhu, J. (2017). Challenges and recent progress in the development of Si anodes for lithium-ion battery. Adv. Energy Mater. 7, 1700715. doi:10.1002/aenm.201700715

Lafuente, B., Downs, R. T., Yang, H., and Stone, N. (2015). "The power of databases: the RRUFF project," in Highlights in mineralogical crystallography. Editors T Armbruster and R M Danisi (Berlin, Germany: W. De Gruyter), 1-30.

Liu, F., and Sun, Z. (2016). Chemical mapping of cement pastes by using confocal Raman spectroscopy. Front. Struct. Civ. Eng. 10, 168-173. doi:10.1007/s11709015-0323-9

Manutchehr-Danai, M. (2013). Dictionary of gems and gemology. New York, NY: Springer, 340-341.

Mao, C., Ruther, R. E., Li, J., Du, Z., and Belharouak, I. (2018). Identifying the limiting electrode in lithium ion batteries for extreme fast charging. Electrochem. Commun. 97, 37-41. doi:10.1016/j.elecom.2018.10.007

Márquez-Mata, C. A., Vega-Carrillo, H. R., Mata Chávez, M. J., and Araiza-Ibarra, J. J. (2019). Caracterización óptica, química y nuclear del ónix mexicano $\left(\mathrm{CaCO}_{3}\right)$, correspondiente a la zona del semidesierto zacatecano. Res. Comput. Sci. 148, 37-47. doi:10.13053/rcs-148-1-4

May, P. W., Smith, J. A., and Rosser, K. N. (2008). $785 \mathrm{~nm}$ Raman spectroscopy of CVD diamond films. Diam. Relat. Mater. 17, 199-203. doi:10.1016/j.diamond. 2007.12.013

Mee, C. (1961). Electrical conductivity of calcium oxide at high electric fields. Nature 192, 350-351. doi:10.1038/192350a0

Minakshi, M., Visbal, H., Mitchell, D. R. G., and Fichtner, M. (2018). Bio-waste chicken eggshells to store energy. Dalton Trans. 47, 16828-16834. doi:10.1039/ C8DT03252A

Minakshi, M., Higley, S., Baur, C., Mitchell, D. R. G., Jones, R. T., and Fichtner, M. (2019). Calcined chicken eggshell electrode for battery and supercapacitor applications. RSC Adv. 9, 26981-26995. doi:10.1039/C9RA04289J
Mo, R., Li, F., Tan, X., Xu, P., Tao, R., Shen, G., et al. (2019). High-quality mesoporous graphene particles as high-energy and fast-charging anodes for lithium-ion batteries. Nat. Commun. 10, 1474. doi:10.1038/s41467-01909274-y

Morales-Flórez, V., Santos, A., Romero-Hermida, I., and Esquivias, L. (2015). Hydration and carbonation reactions of calcium oxide by weathering: kinetics and changes in the nanostructure. Chem. Eng. J. 265, 194-200. doi:10.1016/j.cej. 2014.12.062

Palyanov, Y. N., Kupriyanov, I. N., Sokol, A. G., Borzdov, Y. M., and Khokhryakov, A. F. (2016). Effect of $\mathrm{CO}_{2}$ on crystallization and properties of diamond from ultra-alkaline carbonate melt. Lithos 265, 339-350. doi:10.1016/j.lithos.2016. 05.021

Park, M.-G., Sung, G.-K., Sung, N.-E., Kim, J.-H., and Park, C.-M. (2016). Partially reversible $\mathrm{Li}_{2} \mathrm{O}$ formation in $\mathrm{ZnO}$ : a critical finding supporting realization of highly reversible metal oxide electrodes. J. Power Sources 328, 607-614. doi:10. 1016/j.jpowsour.2016.08.053

Pérez-Díaz, O., Quiroga-González, E., Hansen, S., Silva-González, N. R. Carstensen, J., and Adelung, R. (2019). Fabrication of silicon microwires by a combination of chemical etching steps and their analysis as anode material in Li-ion batteries. Mater. Technol. 34, 785-791. doi:10.1080/10667857.2019. 1629059

Quiroga-González, E., Carstensen, J., and Föll, H. (2013). Optimal conditions for fast charging and long cycling stability of silicon microwire anodes for lithium ion batteries, and comparison with the performance of other Si anode concepts. Energies 6, 5145-5156. doi:10.3390/en6105145

Santamaría-Juárez, G., Gómez-Barojas, E., Quiroga-González, E., Sánchez-Mora, E., Quintana-Ruiz, M., and Santamaría-Juárez, J. D. (2019). Safer modified Hummers' method for the synthesis of graphene oxide with high quality and high yield. Mater. Res. Express. 6, 125631. doi:10.1088/2053-1591/ab4cbf

Schmid, T., and Dariz, P. (2014). Shedding light onto the spectra of lime: Raman and luminescence bands of $\mathrm{CaO}, \mathrm{Ca}(\mathrm{OH})_{2}$ and $\mathrm{CaCO}_{3}$. J. Raman Spectrosc. 46, 141-146. doi:10.1002/jrs.4622

Tian, N., Hua, C., Wang, Z., and Chen, L. (2015). Reversible reduction of $\mathrm{Li}_{2} \mathrm{CO}_{3}$. J. Mater. Chem. 3, 14173-14177. doi:10.1039/C5TA02499D

Wang, L., Zhuo, L., Yu, Y., and Zhao, F. (2013). High-rate performance of SnS2 nanoplates without carbon-coating as anode material for lithium ion batteries. Electrochim. Acta 112, 439-447. doi:10.1016/j.electacta.2013.08.154

Wang, M., Shi, G., Qin, J., and Bai, Q. (2018). Thermal behaviour of calcitestructure carbonates: a powder X-ray diffraction study between 83 and $618 \mathrm{~K}$. Eur. J. Mineral. 30, 939-949. doi:10.1127/ejm/2018/0030-2768

Wright, V. P. (1992). A revised classification of limestones. Sediment. Geol. 76, 177-185. doi:10.1016/0037-0738(92)90082-3

Conflict of Interest: The authors declare that the research was conducted in the absence of any commercial or financial relationships that could be construed as a potential conflict of interest.

Copyright ( 2021 Quiroga-González and Morales-Merino. This is an open-access article distributed under the terms of the Creative Commons Attribution License (CC $B Y$ ). The use, distribution or reproduction in other forums is permitted, provided the original author(s) and the copyright owner(s) are credited and that the original publication in this journal is cited, in accordance with accepted academic practice. No use, distribution or reproduction is permitted which does not comply with these terms. 